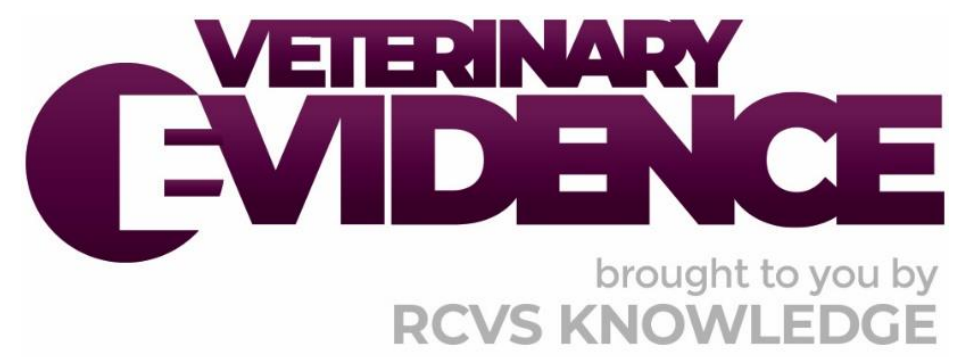

\title{
Cryotherapy of the distal limbs: an effective treatment for equine laminitis following onset of lameness?
}

\section{A Knowledge Summary by}

Lucy Ryde BVMSci (Hons) MRCVS fCMgr ACMI ${ }^{1^{*}}$

\footnotetext{
${ }^{1}$ University of Surrey School of Veterinary Medicine, VSM Building, University of Surrey, Daphne Jackson Road, Guildford GU2 7AL

*Corresponding Author (lucyryde@gmail.com)
}

ISSN: 2396-9776

Published: 09 Dec 2021

in: The Veterinary Evidence journal Vol 6, Issue 4

DOI: https://doi.org/10.18849/ve.v6i4.480

Reviewed by: Joanne Ireland (BVMS PhD CertAVP(EM) FHEA MRCVS) and David Ramey (DVM) 


\section{KNOWLEDGE SUMMARY}

\section{PICO question}

In horses with acute laminitis, does cryotherapy of the distal limbs applied after onset of clinical signs lead to improved clinical outcomes compared to horses treated without cryotherapy?

\section{Clinical bottom line}

\section{Category of research question}

\section{Treatment}

\section{The number and type of study designs reviewed}

Four papers were critically appraised; there were three randomised, controlled trials, and one retrospective cohort study

\section{Strength of evidence}

Weak

\section{Outcomes reported}

There were reduced histological changes and lamellar injury in limbs treated with cryotherapy in the randomised controlled trials and reduced clinical severity of laminitis in horses treated with cryotherapy in the retrospective cohort study

\section{Conclusion}

In horses with acute laminitis there is weak evidence to suggest that cryotherapy of the distal limbs is an effective treatment option when applied following onset of clinical signs. Further randomised, controlled trials should be performed to assess clinical outcomes of cryotherapy in order to draw definitive conclusions

\section{How to apply this evidence in practice}

The application of evidence into practice should take into account multiple factors, not limited to: individual clinical expertise, patient's circumstances and owners' values, country, location or clinic where you work, the individual case in front of you, the availability of therapies and resources.

Knowledge Summaries are a resource to help reinforce or inform decision making. They do not override the responsibility or judgement of the practitioner to do what is best for the animal in their care.

\section{The evidence}

A literature search returned a total of 302 papers, of which four met the inclusion criteria. These papers consisted of three prospective, blinded, experimental, randomised controlled trials (RCTs) (Van Eps et al., 2014; Dern et al., 2018; and Dern et al., 2017), where laminitis was induced in horses using the oligofructose model and the effects of cryotherapy studied. The remaining paper was a retrospective cohort study ( $D$ 'arpe, 2010), which evaluated the outcomes of various treatment protocols for laminitis in the field rather than in an experimental setting.

The quality of evidence of the papers included is variable. All were published within ten years of this paper being written, meaning that they are likely to be representative of treatment protocols used at the present 
day. Experimental RCTs generally produce strong evidence due to the nature of the study type used (Cockcroft, 2019), and the utilisation of blinding in the papers studied will have contributed to the strength of the evidence (Guyatt et al., 2008). However, the study populations used in these RCTs comprised solely a small number of Standardbred horses from research herds, which brings into question the generalisability of results obtained. For this reason, evidence yielded from the RCTs should be categorised as moderate to weak. The retrospective cohort study will have produced weaker evidence than the RCTs (Cockcroft, 2019) due to both the nature of the cohort study design and the fact that it was retrospective, meaning that many variables were not able to be controlled and so significant biases, such as selection bias, may have interfered with the results (Sauerland et al., 2002). For these reasons, the retrospective cohort study included is likely to have yielded weak evidence.

\section{Summary of the evidence}

D’arpe (2010)

\begin{tabular}{|c|c|}
\hline Population: & $\begin{array}{l}\text { Horses diagnosed with laminitis between } 2001 \text { and } 2010 \text { analysed } \\
\text { retrospectively. }\end{array}$ \\
\hline Sample size: & 85 horses. \\
\hline Intervention details: & $\begin{array}{l}\text { - Cases were divided into two groups: } \\
\text { o Group } 1 \text { of } 53 \text { horses that were not treated with } \\
\text { cryotherapy. } \\
\text { o Group } 2 \text { of } 32 \text { horses that were treated with } \\
\text { cryotherapy. }\end{array}$ \\
\hline Study design: & Retrospective cohort study. \\
\hline Outcome studied: & $\begin{array}{l}\text { Subjective assessment - clinical outcome of each case based on pain } \\
\text { management, radiographic changes, and clinical assessment. }\end{array}$ \\
\hline $\begin{array}{l}\text { Main findings: } \\
\text { (relevant to PICO question): }\end{array}$ & $\begin{array}{l}\text { Cryotherapy reduced or eliminated clinical signs within } 12- \\
24 \text { hours of initiation in all horses treated and none } \\
\text { developed rotation of the pedal bone or required further, } \\
\text { more severe treatment interventions. }\end{array}$ \\
\hline
\end{tabular}




\begin{tabular}{|c|c|}
\hline & $\begin{array}{l}\text { White line disease developed } 2-3 \text { months later in } 10 / 15 \\
\text { (67\%) of the horses treated with ice cubes, which was } \\
\text { deemed to be a result of the wet condition of the foot. Only } \\
1 / 17(6 \%) \text { of the horses treated with the cryotherapy } \\
\text { machine developed white line disease. }\end{array}$ \\
\hline Limitations: & $\begin{array}{l}\text { - Additional treatments, such as antibiotics and dietary } \\
\text { changes, were not controlled between the groups. This is a } \\
\text { variable that could have impacted the results. } \\
\text { It was a retrospective study, so the horses were not } \\
\text { randomly assigned to their respective groups. Group } 1 \text { did } \\
\text { not receive cryotherapy as it was not available at the time, } \\
\text { meaning that selection bias was present; horses treated } \\
\text { between } 2001-2007 / 2008 \text { did not receive cryotherapy, with } \\
\text { its use commencing in } 2008 \text {. It is probable that other } \\
\text { variables changed over this time period, increasing the } \\
\text { potential for confounding in this study. } \\
\text { Twelve out of thirty-two (38\%) of the horses treated with } \\
\text { cryotherapy were unable to be followed up after the study. } \\
\text { This means that the longer-term effects of cryotherapy are } \\
\text { unknown in } 12 \text { of the subjects. There was also a substantial } \\
\text { loss to follow-up in Group 1, weakening the evidence the } \\
\text { paper provides as the longer-term effects of either } \\
\text { treatment are unknown. }\end{array}$ \\
\hline
\end{tabular}

Van Eps et al. (2014)

\begin{tabular}{|c|c|}
\hline Population: & $\begin{array}{l}\text { Standardbred geldings aged } 3-11 \text { years, ranging from } 430-548 \mathrm{~kg} \text {, } \\
\text { with no lameness and no gross or radiographic abnormalities of the } \\
\text { hooves. }\end{array}$ \\
\hline Sample size: & Eight horses. \\
\hline Intervention details: & $\begin{array}{l}\text { - All horses were housed and fed in stables for } 4 \text { weeks prior } \\
\text { to the study. } \\
\text { - Laminitis was induced in all horses using the oligofructose } \\
\text { model via nasogastric administration of the bolus dose ( } 10 \\
\mathrm{~g} / \mathrm{kg} \text { bodyweight of oligofructose, up to a maximum dose of } \\
4.2 \mathrm{~kg} \text { ). } \\
\text { - Immediately after induction, each horse was confined to } \\
\text { - } \text { stocks for the remainder of the study. } \\
\text { thermistors, and human pedometers were attached to both } \\
\text { forelimbs to monitor the frequency of weight-shifting as a } \\
\text { marker for pain. } \\
12 \text { hours after induction of laminitis, horses were monitored } \\
\text { for the development of lameness by pedometer counts and } \\
\text { gait analysis by two individuals every } 4 \text { hours. } \\
\text { Once lameness was detected at walk by both investigators, } \\
\text { one forelimb was continuously cooled, and the other } \\
\text { forelimb was maintained at ambient temperature. The } \\
\text { forelimbs designated for each treatment alternative were } \\
\text { randomly assigned. }\end{array}$ \\
\hline
\end{tabular}




\begin{tabular}{|c|c|}
\hline & $\begin{array}{l}\text { Perineural analgesia via palmar nerve block was given to all } \\
\text { horses using } 2.5 \mathrm{ml} \text { of } 0.25 \% \text { bupivacaine and } 2.5 \mathrm{ml} \text { of } 2 \% \\
\text { mepivacaine per site, and all horses received } \\
\text { phenylbutazone ( } 4.4 \mathrm{mg} / \mathrm{kg} \text { bodyweight IV) at the onset of } \\
\text { lameness and again between } 12-24 \text { hours after the onset of } \\
\text { lameness. } \\
\text { - Cryotherapy was achieved by placing the limb in a rubber } \\
\text { boot containing } 50 \% \text { cubed ice and } 50 \% \text { water to a level just } \\
\text { below the carpus. } \\
36 \text { hours after the detection of lameness, horses were } \\
\text { euthanised via pentobarbital sodium ( } 20 \mathrm{mg} / \mathrm{kg} \text { bwt IV) and } \\
\text { the forelimb dorsal lamellae were dissected from the hoof of } \\
\text { both forelimbs and processed for light microscopy. }\end{array}$ \\
\hline Study design: & Prospective, randomised, controlled, blinded, experimental trial. \\
\hline Outcome studied: & $\begin{array}{l}\text { Objective assessment }- \text { dorsal lamellar sections were examined } 36 \\
\text { hours after onset of lameness by two blinded observers to } \\
\text { determine histological score ( } 0-4 \text { [normal to severe]) and a } \\
\text { morphometric analysis was performed on each. }\end{array}$ \\
\hline $\begin{array}{l}\text { Main findings: } \\
\text { (relevant to PICO question): }\end{array}$ & $\begin{array}{l}\text { - Continuous digital hypothermia significantly reduced the } \\
\text { severity of lamellar injury in the horses studied. } \\
\text { - Four out of eight ( } 50 \% \text { ) of the lamellar sections at ambient } \\
\text { temperature had a histological score of } 4 \text { (most severe) } \\
\text { compared with } 0 \text { of the iced sections and the median } \\
\text { histological scores of the ambient sections were significantly } \\
\text { higher than those of the iced sections. } \\
\text { - The histological changes noted in the limbs treated with } \\
\text { cryotherapy were limited to only the mildest histological } \\
\text { changes able to be observed using light microscopy. } \\
\text { Pain, as judged by the weight-shifting monitored by the } \\
\text { pedometers, was found to be significantly reduced in the } \\
\text { limbs treated with cryotherapy compared to those treated } \\
\text { at ambient temperature - horses were noted to stand still } \\
\text { on the cryotherapy-treated limb and weight shift on the } \\
\text { ambient limb. }\end{array}$ \\
\hline Limitations: & $\begin{array}{l}\text { - Hypothermia was initiated immediately after onset of } \\
\text { lameness. In clinical scenarios, there is likely to be a delay in } \\
\text { initiation of hypothermia. } \\
\text { - The researchers only performed histological analysis of the } \\
\text { lamellae, rather than any study of clinical progression of the } \\
\text { laminitis. This makes extrapolation of the results to clinical } \\
\text { outcomes more difficult. } \\
\text { - The decreased pain noted in the limbs treated with } \\
\text { cryotherapy could have been due to the analgesic properties } \\
\text { of cryotherapy rather than any disease-modifying effects of } \\
\text { the treatment. } \\
\text { The study only continued for } 36 \text { hours for humane reasons, } \\
\text { so conclusions cannot be drawn on the progression of } \\
\text { laminitis after } 36 \text { hours and whether the laminitis lesions } \\
\text { present in the limbs would have deteriorated after the } \\
\text { cessation of cryotherapy. }\end{array}$ \\
\hline
\end{tabular}




\begin{tabular}{|l|l|}
\hline - & $\begin{array}{l}\text { Results were obtained using artificially induced laminitis and } \\
\text { so it may not be possible to directly extrapolate the results } \\
\text { to naturally occurring laminitis. }\end{array}$ \\
- & A small sample size was studied, with the study population \\
comprising eight Standardbred geldings, which is unlikely to \\
be representative of the wider population.
\end{tabular}

\begin{tabular}{|c|c|}
\hline \multicolumn{2}{|l|}{ Dern et al. (2017) } \\
\hline Population: & $\begin{array}{l}\text { Standardbred geldings aged } 3-11 \text { years with no lameness and no } \\
\text { abnormalities of the hooves detectable by gross or radiographic } \\
\text { examination. This is a secondary analysis of the same horses used in } \\
\text { Van Eps, } 2014 \text {. }\end{array}$ \\
\hline Sample size: & Eight horses. \\
\hline Intervention details: & $\begin{array}{l}\text { - All eight horses had laminitis induced using the oligofructose } \\
\text { model via nasogastric administration of the bolus dose ( } 10 \\
\text { g/kg bodyweight of oligofructose, up to a maximum dose of } \\
4.2 \mathrm{~kg} \text { ). } \\
\text { - The horses were all confined to stocks for the duration of } \\
\text { the study and pedometers were attached to each forelimb } \\
\text { to monitor frequency of weight-shifting as a marker for pain. } \\
\text { Hoof wall temperature was measured using hoof wall } \\
\text { thermistors. } \\
\text { - Horses were closely monitored for the onset of lameness by } \\
\text { pedometer counts and gait evaluation performed by two } \\
\text { observers every } 4 \text { hours. } \\
\text { - Lameness of one or both forelimbs at walk was the } \\
\text { timepoint for initiation of cryotherapy - one forelimb was } \\
\text { cooled and the other maintained at ambient temperature. } \\
\text { All horses were given perineural analgesia in both forelimbs } \\
\text { via palmar nerve block using } 2.5 \text { ml of } 0.25 \% \text { bupivacaine } \\
\text { and } 2.5 \text { ml of } 2 \% \text { mepivacaine per site. Phenylbutazone (4.4 } \\
\text { mg/kg bodyweight IV) was also given to all horses at the } \\
\text { onset of lameness and again between } 12-24 \text { hours after the } \\
\text { onset of lameness. } \\
36 \text { hours after the initiation of cryotherapy, all horses were } \\
\text { euthanised with pentobarbital sodium ( } 20 \text { mg/kg } \\
\text { bodyweight IV) and lamellar tissue samples were collected } \\
\text { from both forelimbs and fixed and processed for light } \\
\text { microscopy. }\end{array}$ \\
\hline Study design: & Prospective, controlled, blinded, experimental trial. \\
\hline Outcome studied: & $\begin{array}{l}\text { Objective assessment - horses were euthanised after } 36 \text { hours to } \\
\text { study concentrations of inflammatory markers in the lamellae to } \\
\text { compare the differences between the limbs treated with } \\
\text { cryotherapy with those treated at ambient temperature. The results } \\
\text { were also compared with the data from a previous study (Van Eps et } \\
\text { al., 2014) which utilised data from a study conducted by Leise et al. } \\
\text { (2011), documenting inflammatory markers present in the lamellae } \\
\text { of normal horses that had not had laminitis induced. }\end{array}$ \\
\hline
\end{tabular}




\begin{tabular}{|c|c|}
\hline $\begin{array}{c}\text { Main findings: } \\
\text { (relevant to PICO question): }\end{array}$ & $\begin{array}{l}\text { Digital cryotherapy had no significant effect on increasing or } \\
\text { decreasing the number of inflammatory markers present in the } \\
\text { lamellae. }\end{array}$ \\
\hline Limitations: & $\begin{array}{l}\text { The researchers only studied inflammatory markers present } \\
\text { in the lamellae, rather than looking at clinical signs or } \\
\text { pathology of the lamellae. }\end{array}$ \\
- & $\begin{array}{l}\text { Results were obtained using artificially induced laminitis and } \\
\text { so the results may not be directly extrapolatable to naturally } \\
\text { occurring laminitis. }\end{array}$ \\
A small sample size of eight Standardbred geldings was \\
studied, which is unlikely to be representative of the wider \\
population. A power calculation was not carried out to \\
determine whether the sample size was large enough. \\
The study only continued for 36 hours for humane reasons, \\
so conclusions cannot be drawn on the progression of \\
laminitis after 36 hours and whether the laminitis lesions \\
present in the limbs would have deteriorated after the \\
cessation of cryotherapy.
\end{tabular}

\section{Dern et al. (2018)}

\begin{tabular}{|c|c|}
\hline Population: & $\begin{array}{l}\text { Standardbred geldings aged } 3-11 \text { years with no evidence of } \\
\text { lameness or gross abnormalities of the hooves. }\end{array}$ \\
\hline Sample size: & $\begin{array}{l}15 \text { horses: seven horses administered oligofructose to induce } \\
\text { laminitis, eight horses which acted as controls. }\end{array}$ \\
\hline Intervention details: & $\begin{array}{l}\text { - Horses were randomly assigned to one of two groups - } \\
\text { seven horses underwent laminitis induction via nasogastric } \\
\text { administration of the bolus dose ( } 10 \mathrm{~g} / \mathrm{kg} \text { bolus of } \\
\text { oligofructose, up to a maximum dose of } 4.2 \mathrm{~kg} \text { ). Eight horses } \\
\text { acted as the control group and did not have laminitis } \\
\text { induced. } \\
\text { - All horses were placed in stocks for the duration of the study } \\
\text { and had constant access to hay and water. } \\
\text { - Cryotherapy was performed on one randomly assigned } \\
\text { forelimb on all horses } 12 \text { hours after induction of laminitis. } \\
\text { Twelve hours was chosen as it represents the timeframe } \\
\text { during which horses consistently start to show clinical signs } \\
\text { of laminitis. } \\
\text { - In the control group, cryotherapy was initiated } 12 \text { hours } \\
\text { after the beginning of confinement in stocks. } \\
\text { Cryotherapy was achieved by maintaining one forelimb in a } \\
\text { rubber boot containing } 50 \% \text { ice and } 50 \% \text { water to the level } \\
\text { of the proximal metacarpus. } \\
\text { Forelimb hoof temperature was monitored using } \\
\text { thermistors and human pedometers were attached to each } \\
\text { forelimb to monitor the frequency of weight-shifting as a } \\
\text { marker for pain. Two-hourly recording of vital parameters } \\
\text { was also performed. } \\
\text { A single dose of phenylbutazone was administered to all } \\
\text { horses in the treatment group at the onset of signs of } \\
\text { laminitis (determined by evidence of weight-shifting). }\end{array}$ \\
\hline
\end{tabular}




\begin{tabular}{|c|c|}
\hline & $\begin{array}{l}\text { - All horses were euthanised } 24 \text { hours after initiation of } \\
\text { cryotherapy with pentobarbital sodium ( } 20 \mathrm{mg} / \mathrm{kg} \\
\text { bodyweight IV) and lamellar tissue samples collected from } \\
\text { both forelimbs to study inflammatory mediators and } \\
\text { leukocyte numbers, which were assessed using qPCR and } \\
\text { immunohistochemistry. The sections were either snap } \\
\text { frozen or fixed and processed for light microscopy. }\end{array}$ \\
\hline Study design: & Prospective, randomised, controlled, blinded, experimental trial. \\
\hline Outcome studied: & $\begin{array}{l}\text { Objective assessment - lamellar tissue samples were obtained } 24 \\
\text { hours after initiation of continuous digital hypothermia. } \\
\text { Concentrations of inflammatory mediators and leukocyte numbers } \\
\text { in the lamellar tissue were assessed using qPCR and } \\
\text { immunohistochemistry. Subjective assessment - histopathological } \\
\text { scores were assigned to each section from 0-4 (normal to severe) by } \\
\text { two blinded observers. }\end{array}$ \\
\hline $\begin{array}{l}\text { Main findings: } \\
\text { (relevant to PICO question): }\end{array}$ & $\begin{array}{l}\text { Pedometer data showed increased weight-shifting in the } \\
\text { limbs treated at ambient temperature compared with those } \\
\text { treated with cryotherapy, signifying increased pain in the } \\
\text { ambient limbs. } \\
\text { - Median histological scores were significantly lower in the } \\
\text { horses treated with cryotherapy than those maintained at } \\
\text { ambient temperature. } \\
\text { - Lamellar leukocyte numbers were significantly decreased in } \\
\text { horses treated with cryotherapy. } \\
\text { - No difference was seen in lamellar mRNA concentrations of } \\
\text { inflammatory cytokines. } \\
\text { Two inflammatory chemokines were found to be decreased } \\
\text { in horses treated with cryotherapy. }\end{array}$ \\
\hline Limitations: & $\begin{array}{l}\text { - The study was only conducted for } 24 \text { hours for humane } \\
\text { reasons so conclusions cannot be drawn on the progression } \\
\text { of laminitis after } 24 \text { hours and whether the laminitis lesions } \\
\text { present in the limbs would have deteriorated following } \\
\text { cessation of cryotherapy. } \\
\text { - The researchers only performed histological analysis of the } \\
\text { lamellae, rather than any study of clinical progression of the } \\
\text { laminitis. This makes extrapolation of the results to clinical } \\
\text { outcomes more difficult. } \\
\text { The decreased pain noted in the limbs treated with } \\
\text { cryotherapy could have been due to the analgesic properties } \\
\text { of cryotherapy rather than any disease-modifying effects of } \\
\text { the treatment. } \\
\text { Only one horse was lame at the time that cryotherapy was } \\
\text { commenced and three of seven horses only showed Obel } \\
\text { grade } 1 \text { lameness } 24 \text { hours post-laminitis induction. This } \\
\text { means that cryotherapy would have been given } \\
\text { prophylactically in these horses. } \\
\text { Results were obtained using artificially induced and so the } \\
\text { results may not be directly extrapolatable to naturally } \\
\text { occurring laminitis. }\end{array}$ \\
\hline
\end{tabular}


- A small sample size of 15 Standardbred geldings was studied

- this is unlikely to be representative of the general

population.

\section{Appraisal, application and reflection}

Cryotherapy of the distal limbs is a fairly new treatment option for laminitis. It has come to the fore in recent years as an effective prophylactic measure to prevent the onset of laminitis in horses treated during an at-risk period (Kullmann et al., 2013). However, cryotherapy has had somewhat limited clinical use thus far, as the majority of laminitis cases occur without warning and so treatment prior to onset is not usually feasible in a clinical setting. The efficacy of cryotherapy as a treatment option once clinical signs of laminitis are apparent is yet to be determined. If cryotherapy were shown to be effective at halting the progression of structural changes in the lamellae and reducing the severity of the condition, its use could potentially change the way laminitis is managed and improve outcomes for affected horses. This Knowledge Summary seeks to determine whether cryotherapy of the distal limbs is an effective treatment for laminitis when applied following the onset of clinical signs.

Of the three papers deemed to produce 'moderate-to-weak' evidence (as noted in the 'Evidence' section above), two found positive effects of cryotherapy (Van Eps et al., 2014; and Dern et al., 2018) and one found no effect (Dern et al., 2017).

Dern et al. (2017) studied the effect of cryotherapy on inflammatory signalling in the lamellae during an episode of laminitis and found no significant difference between treating the distal limbs with cryotherapy and treating at ambient temperature. However, whilst inflammation is thought to play a role in the pathology of laminitis, it is possible that cryotherapy is still effective at treating laminitis, but that the cryotherapy works via a different mechanism than by controlling inflammatory signalling. This may explain why no significant differences were found in this study. Thus, the results of this study do not necessarily negate the use of cryotherapy as a treatment for laminitis, although they do not support it.

Dern et al. (2018) also studied the effect of cryotherapy on inflammatory signalling in the lamellae in horses with laminitis. In addition, lamellar histological grade and leukocyte numbers were also studied. Similarly, Dern et al. (2018) found limited effects of cryotherapy on inflammatory signalling, but did note a slight decrease. This study did, however, find significantly lower histological grades and leukocyte numbers in limbs treated with cryotherapy. A lower histological grade indicates that there was reduced stretching and deterioration of the secondary lamellae, the cause of displacement and rotation of the pedal bone in laminitis (Belknap, 2015), and so suggests that cryotherapy would be an effective treatment. This study supports the conclusions drawn by Dern et al. (2017) that cryotherapy of the distal limbs likely acts to treat laminitis via a mechanism other than by reducing inflammatory signalling.

It should, however, be noted that Dern et al. (2018) initiated cryotherapy at a 'clinically relevant timepoint', rather than at the onset of clinical signs. A 'clinically relevant timepoint' was defined as 12 hours post induction of laminitis, as this was deemed to be the most likely time for clinical signs to develop following induction with the oligofructose model. This assumption is supported by the literature (Van Eps \& Pollitt, 2010), but it is important to note that in the study performed by Dern et al. (2018) only one horse was lame at the time that cryotherapy was commenced, and three of the seven horses only showed Obel grade 1 lameness at 24 hours post-induction. This means that cryotherapy would have been given prophylactically in these horses, rather than as a treatment. This weakens the evidence provided by Dern et al. (2018) in showing that cryotherapy of the distal limbs is an effective treatment option for laminitis when initiated after the onset of clinical signs.

Van Eps et al. (2014) initiated cryotherapy following the onset of lameness at walk in horses induced with the oligofructose laminitis model. The study found that cryotherapy significantly reduced the severity of lamellar injury and prevented all limbs treated from progressing to the most severe grade of lamellar degradation. This 
was in stark contrast to $50 \%$ of the ambiently treated limbs being classified at this most severe grade. This study provides moderate evidence for the use of cryotherapy of the distal limbs as an effective treatment for laminitis, limited by the lack of clinical progression of the cases as the horses were euthanised before this could be assessed.

All of the papers discussed thus far (Dern et al., 2017; Dern et al., 2018; and Van Eps et al., 2014) have been RCTs. This is a strength, as it means they are likely to have robust study designs and produce strong evidence (Cockcroft, 2019). However, there are a number of limitations associated with these studies. All of the studies artificially induced laminitis using the oligofructose laminitis model. This model is based on sepsis-related laminitis (Godman et al., 2016) and so may not be reflective of naturally occurring cases, of which the vast majority occur due to endocrinopathies and hyperinsulinaemia (Belknap, 2015). Additionally, small sample sizes of young, healthy, Standardbred horses were used, meaning that the horses studied are unlikely to be representative of the wider equine population, particularly of the population at greatest risk of laminitis (Faber \& Fonseca, 2014). Both of these limitations weaken the basis for the application of the results to clinical cases of laminitis occurring in the field.

Furthermore, each of the RCTs studied not the clinical outcome of the trial, but the histological effects on the lamellae and the presence of inflammatory mediators. Whilst the pathology of laminitis is understood to be associated with elongation and deterioration of the lamellae (Belknap, 2015), without clinical assessment of the subjects, it would be problematic to infer from these studies that cryotherapy of the distal limbs will improve clinical outcomes of affected horses. This further limits the ability to claim that cryotherapy is an effective treatment for horses with laminitis in the field.

Moreover, in the studies performed by Van Eps et al. (2014) and Dern et al. (2017), cryotherapy was initiated immediately following onset of lameness (these studies utilised the same horses, with Dern et al. (2017) using the data collected in 2014 to perform additional analysis). This is not necessarily reflective of how laminitis is treated in the field - in a naturally occurring case of laminitis, there would likely be a delay in initiation of treatment (for example, lameness may not be detected instantly and there may be a delay between noticing the problem, calling a veterinarian for advice, and performing any diagnostics before beginning treatment). These studies do not allow for extrapolation of the efficacy of cryotherapy when a number of hours or days have passed before treatment is commenced. In addition, the studies only continued for 36 hours, so conclusions cannot be drawn on the longer-term progression of laminitis and whether the laminitis lesions present in the limbs would have deteriorated after the cessation of cryotherapy.

A retrospective cohort study was performed to explore treatment outcomes of naturally occurring cases of laminitis in the field, with a larger sample size of 85 horses (D'arpe, 2010). D'arpe (2010) found that 0/32 (0\%) of horses treated with cryotherapy developed subsequent rotation of the pedal bone, whereas some horses treated with ambient limb therapy did develop pedal bone rotation. This may suggest that cryotherapy is a beneficial treatment option. However, the reporting of results in this paper does not allow for direct comparison between treatment groups, meaning that it is difficult to draw conclusions on whether treatment with cryotherapy resulted in better outcomes than treatment without. No deleterious effects were seen in horses treated with cryotherapy, indicating that it is safe to use. Additionally, as the study was performed in the field, there would likely have been a delay between the onset of clinical signs and initiation of treatment, which reflects a more feasible use of cryotherapy in clinical practice than that which is performed in the RCTs. The results of this study suggest that cryotherapy of the distal limbs may be an effective treatment for laminitis.

However, retrospective cohort studies have significant limitations which can lead to bias (Sauerland et al., 2002). Little detail is provided on decisions regarding the allocation of horses to treatment groups in D'arpe (2010). However, it can be inferred that the horses were not randomly assigned to treatment groups, as all the horses treated with cryotherapy were those who developed laminitis after cryotherapy became available as a treatment option in 2008. Horses who developed laminitis prior to 2008 were treated with alternative therapies, as cryotherapy was not available. This may have given rise to bias in the treatment groups and thus weakens the strength of conclusions able to be drawn from the study. It is also possible that the horses 
treated with cryotherapy in this study were treated so because they were assessed to be good candidates for cryotherapy (i.e. perhaps they had less severe laminitis, or perhaps the laminitis was identified particularly early in the disease course). The paper indicates that $20 / 53(38 \%)$ of the non-cryotherapy cases were moderate to highly severe or very high severity whereas that information is not provided for the cryotherapy cases. The possibility for bias here further weakens the conclusion that cryotherapy is a good treatment option for all horses with laminitis. Furthermore, additional treatment protocols (e.g., dietary restriction, length of box rest and pain relief) were not controlled between groups. A lack of control of these variables could have impacted the results. There may also be a further possibility of bias in this study given that the author of the study invented the boots used in the 17 successful cryotherapy cases, representing a potential financial conflict of interest that may have biased the results. These limitations weaken the argument for application of cryotherapy to the wider equine population.

In conclusion, there is weak evidence to support the use of cryotherapy of the distal limbs as a treatment for acute laminitis in horses after the onset of clinical signs. The evidence from the RCTs largely supports the use of cryotherapy, and, importantly, no studies found negative effects associated with its use. Whilst RCTs can produce strong evidence (Cockcroft, 2019), they do have certain limitations, mostly surrounding their artificial nature. These limitations are particularly problematic when attempting to extrapolate results found on histology to clinical outcomes of cases; there is certainly strong evidence that cryotherapy of the distal limbs reduces structural degradation of the secondary lamellae during acute laminitis, but it is more difficult to draw definitive conclusions regarding clinical outcomes from these studies. Many of these limitations of RCTs can be overcome by field studies, as was discussed regarding the study performed by D'arpe (2010). However, field studies produce much weaker evidence than RCTs, and this particular field study has a number of important limitations including selection bias and poor reporting. Considering each of these studies in relation to one another, it appears that there is evidence to support the use of cryotherapy of the distal limbs as a treatment for laminitis after the onset of clinical signs. The evidence should be categorised as weak, as this conclusion can only be drawn when the studies are viewed in combination with each other in order to account for their respective limitations. Further randomised, controlled trials should be performed to assess the efficacy of cryotherapy on improving clinical outcomes of laminitis cases when applied after the onset of clinical signs.

\section{Methodology Section}

\section{Search Strategy}

Databases searched and dates CAB Abstracts on CAB Direct 1973-May 2021

covered: PubMed on NIH Platform 1949-May 2021

Scopus 1984-May 2021

Search terms: $\quad$ CAB Abstracts:

(equine* OR horse* OR pony OR ponies) AND (laminiti*) AND (cryotherapy OR hypothermia OR "cold therapy" OR ice OR icing OR cold)

\section{PubMed:}

(equine* OR horse* OR pony OR ponies) AND (laminiti*) AND (cryotherapy OR hypothermia OR "cold therapy" OR ice OR icing OR cold)

\section{Scopus:}

(equine* OR horse* OR pony OR ponies) AND (laminiti*) AND (cryotherapy OR hypothermia OR "cold therapy" OR ice OR icing OR cold) AND NOT (bovine*) AND (LIMIT-TO (DOCTYPE, "ar"))

Dates searches performed: 27 May 2021 


\section{Exclusion / Inclusion Criteria}

Studies were limited to in vivo studies, which evaluated the use of cryotherapy applied only after the onset of clinical signs of laminitis.

\begin{tabular}{|c|l|}
\hline Exclusion: & $\begin{array}{l}\text { Non-English language publication; in vitro studies; study group } \\
\text { received prophylactic cryotherapy only; study group did not have } \\
\text { laminitis. }\end{array}$ \\
\hline Inclusion: & $\begin{array}{l}\text { Any study of horses or ponies undergoing treatment for laminitis } \\
\text { using cryotherapy administered after the onset of clinical signs. }\end{array}$ \\
\hline
\end{tabular}

\begin{tabular}{|c|c|c|c|c|c|c|c|c|}
\hline \multicolumn{9}{|c|}{ Search Outcome } \\
\hline Database & $\begin{array}{c}\text { Number of } \\
\text { results }\end{array}$ & $\begin{array}{l}\text { Excluded - } \\
\text { By preliminary } \\
\text { title screen }\end{array}$ & $\begin{array}{l}\text { Excluded - } \\
\text { Non-English } \\
\text { language } \\
\text { publication }\end{array}$ & $\begin{array}{l}\text { Excluded - } \\
\text { In vitro } \\
\text { study }\end{array}$ & $\begin{array}{c}\text { Excluded - } \\
\text { Study group } \\
\text { received } \\
\text { prophylactic } \\
\text { cryotherapy } \\
\text { only }\end{array}$ & $\begin{array}{l}\text { Excluded - } \\
\text { Study } \\
\text { group did } \\
\text { not have } \\
\text { laminitis }\end{array}$ & $\begin{array}{l}\text { Excluded - } \\
\text { Duplicate } \\
\text { paper }\end{array}$ & $\begin{array}{c}\text { Total } \\
\text { relevant } \\
\text { papers }\end{array}$ \\
\hline $\begin{array}{l}\mathrm{CAB} \\
\text { Abstracts }\end{array}$ & 80 & 60 & 1 & 1 & 9 & 3 & 2 & 4 \\
\hline PubMed & 36 & 23 & 0 & 1 & 6 & 2 & 0 & 4 \\
\hline Scopus & 186 & 166 & 2 & 1 & 9 & 4 & 0 & 4 \\
\hline \multicolumn{8}{|c|}{ Total relevant papers when duplicates removed } & 4 \\
\hline
\end{tabular}




\section{CONFLICT OF INTEREST}

The authors declare no conflict of interest.

\section{REFERENCES}

1. Belknap, J. (2015). Laminitis In Horses. [online] MSD Veterinary Manual. Available at: https://www.msdvetmanual.com/musculoskeletal-system/lameness-in-horses/laminitis-inhorses [Accessed 27 October 2020].

2. Cockcroft, P. (2019). Grading the evidence and writing the clinical bottom line. Veterinary Evidence. 4(4). DOI: https://doi.org/10.18849/ve.v4i4.305

3. D'arpe, L. (2010). The ice shoe to prevent and treat equine laminitis. European Society of Veterinary Orthopaedics and Traumatology, 19, 196-199.

4. Dern, K., Watts, M., Werle, B., van Eps, A., Pollitt, C. \& Belknap, J. (2017). Effect of Delayed Digital Hypothermia on Lamellar Inflammatory Signaling in the Oligofructose Laminitis Model. Journal of Veterinary Internal Medicine. 31(2), 575-581. DOI: https://doi.org/10.1111/jvim.14633

5. Dern, K., van Eps, A., Wittum, T., Watts, M., Pollitt, C. \& Belknap, J. (2018). Effect of Continuous Digital Hypothermia on Lamellar Inflammatory Signaling When Applied at a Clinically-relevant Timepoint in the Oligofructose Laminitis Model. Journal of Veterinary Internal Medicine. 32(1), 450-458. DOI: https://doi.org/10.1111/ivim.15027

6. Faber, J. \& Fonseca, L.M. (2014). How sample size influences research outcomes. Dental Press Journal of Orthodontics. 19(4), 27-29. DOI: https://doi.org/10.1590/2176-9451.19.4.027-029.ebo

7. Godman, J., Burns, T., Kelly, C., Watts, M., Leise, B., Schroeder, E., van Eps, A. \& Belknap, J. (2016). The effect of hypothermia on influx of leukocytes in the digital lamellae of horses with oligofructoseinduced laminitis. Veterinary Immunology and Immunopathology. 178, 22-28. DOI: https://doi.org/10.1016/j.vetimm.2016.05.013

8. Guyatt, G.H., Oxman, A.D., Kunz, R., Vist, G.E., Falck-Ytter, Y. \& Schünemann, H.J. (2008). What is "quality of evidence" and why is it important to clinicians? BMJ. 336(7651), 995-998.

DOI: https://doi.org/10.1136/bmj.39490.551019.BE

9. Kullmann, A., Holcombe, S.J., Hurcombe, S.D., Roessner, H.A., Hauptman, J.G., Geor, R.J. \& Belknap, J. (2013). Prophylactic digital cryotherapy is associated with decreased incidence of laminitis in horses diagnosed with colitis. Equine Veterinary Journal. 46(5), 554-559.

DOI: https://doi.org/10.1111/evi.12156

10. Leise, B.S., Faleiros, R.R., Watts, M., Johnson, P.J., Black, S.J. \& Belknap, J.K. (2011). Laminar inflammatory gene expression in the carbohydrate overload model of equine laminitis. Equine Veterinary Journal. 43(1), 54-61. DOI: https://doi.org/10.1111/i.2042-3306.2010.00122.x

11. Sauerland, S., Lefering, R. \& Neugebauer, E.A.M. (2002). Retrospective clinical studies in surgery: potentials and pitfalls. Journal of Hand Surgery. 27(2), 117-121.

DOI: https://doi.org/10.1054\%2FJHSB.2001.0703

12. Van Eps, A.W. \& Pollitt, C.C. (2010). Equine laminitis induced with oligofructose. Equine Veterinary Journal. 38(3), 203-208. DOI: https://doi.org/10.2746/042516406776866327

13. Van Eps, A.W., Pollitt, C.C., Underwood, C., Medina-Torres, C.E., Goodwin, W.A. \& Belknap, J.K. (2014). Continuous digital hypothermia initiated after the onset of lameness prevents lamellar failure in the oligofructose laminitis model. Equine Veterinary Journal. 46(5), 625-630.

DOI: https://doi.org/10.1111/evj.12180 


\section{EVIIDEFeE

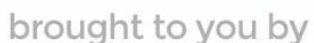 \\ RCVS KNOWLEDGE}

\section{Intellectual Property Rights}

Authors of Knowledge Summaries submitted to RCVS Knowledge for publication will retain copyright in their work, and will be required to grant RCVS Knowledge a non-exclusive license of the rights of copyright in the materials including but not limited to the right to publish, re-

publish, transmit, sell, distribute and otherwise use the materials in all languages and all media throughout the world, and to license or permit others to do so.

\section{Disclaimer}

Knowledge Summaries are a peer-reviewed article type which aims to answer a clinical question based on the best available current evidence. It does not override the responsibility

of the practitioner. Informed decisions should be made by considering such factors as individual clinical expertise and judgement along with patient's circumstances and owners' values. Knowledge Summaries are a resource to help inform and any opinions expressed within the Knowledge Summaries are the author's own and do not necessarily reflect the view of the RCVS Knowledge. Authors are responsible for the accuracy of the content. While the

Editor and Publisher believe that all content herein are in accord with current recommendations and practice at the time of publication, they accept no legal responsibility

for any errors or omissions, and make no warranty, express or implied, with respect to material contained within.

For further information please refer to our Terms of Use.

RCVS Knowledge is the independent charity associated with the Royal College of Veterinary Surgeons (RCVS). Our ambition is to become a global intermediary for evidence based veterinary knowledge by providing access to information

that is of immediate value to practicing veterinary professionals and directly contributes to evidence based clinical decision-making.

https://www.veterinaryevidence.org/

RCVS Knowledge is a registered Charity No. 230886.

Registered as a Company limited by guarantee in England and Wales No. 598443.

Registered Office: Belgravia House, 62-64 Horseferry Road, London SW1P 2AF

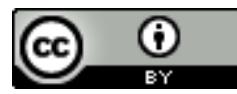

This work is licensed under a Creative Commons Attribution 4.0 International License 